\title{
THIRD VENTRICULOSTOMY THROUGH THE LAMINA TERMINALIS FOR INTRACRANIAL PRESSURE MONITORING AFTER ANEURYSM SURGERY
}

\section{Technical note}

\author{
Jorge L. Kraemer'1, Pedro L. Gobbato², Yuri M. Andrade-Souza ${ }^{3}$
}

\begin{abstract}
Objective: A new ventriculostomy technique through the lamina terminalis is described. This technique is applied mainly during aneurysm surgery at the acute stage. Method: Thirteen patients were operated on intracranial aneurysms and, during the procedure, had the lamina terminalis fenestrated. A ventricular catheter was inserted into the third ventricule, left in place and connected to an external drainage system for further intracranial pressure (ICP) monitoring and/or cerebrospinal fluid (CSF) drainage. Results: ICP readings and CSF drainage were obtained in all cases. No complication was recorded. Conclusion: Third ventriculostomy through the lamina terminalis is a simple and easy technique that can be used as an alternative to conventional ventriculostomy. This procedure can be indicated in cases where the ventricule is not reached by means of another technique, and when the decision to perform ventriculostomy is made at the end of aneurysm surgery.
\end{abstract}

KEY WORDS: cerebral aneurysm, ventricular drainage, third ventricle, intracranial pressure, operative technique.

\begin{abstract}
Terceiroventriculostomia via lamina terminalis para monitorização de pressão intracraniana após cirurgia de aneurisma: nota técnica

RESUMO - Objetivo: Uma nova técnica de ventriculostomia através da lamina terminalis é descrita para utilização durante cirurgia de aneurisma na fase aguda. M étodo: Treze pacientes foram operados de aneurisma cerebral e, durante o procedimento, tiveram a lamina terminalis fenestrada. Um catéter ventricular foi inserido no terceiro ventrículo e conectado a um sistema de drenagem externa para monitorização da pressão intracraniana (PIC) e/ou drenagem de líquor (LCR). Resultados: A leitura da PIC e a drenagem do LCR foram obtidas em todos os casos. Não se evidenciaram complicações. Conclusão: A terceiroventriculostomia através da lamina terminalis é uma técnica simples e fácil, que pode ser usada como uma alternativa à ventriculostomia convencional. Esse procedimento pode ser indicado em casos em que as técnicas convencionais falham, ou quando a decisão de realizar a ventriculostomia é tomada ao final da cirurgia de aneurisma.
\end{abstract}

PALAVRAS-CHAVE: aneurisma cerebral, drenagem ventricular, terceiro ventrículo, pressão intracraniana, técnica operatória.

Early surgery for treatment of ruptured intracranial aneurysms is well established ${ }^{1,2}$. Intracranial pressure (ICP), monitoring, by means of a ventriculostomy, may improve the outcome as it decreases the incidence of ischaemic complications and hydrocephalus $^{3-5}$. However, ventricular puncture in patients with acute Subarachinoide Hemorrhage (SAH) is neither atraumatic ${ }^{6}$ nor easy to be performed. Fur- thermore, opening the lamina terminalis influences a better outcome in patients with ruptured intracranial aneurysms ${ }^{7,8}$.

We present our preliminary experience with ICP monitoring by using a catheter placed directly in the third ventricle through the lamina terminalis. All patients were operated in the acute stage of a ruptured intracranial aneurysm.

\footnotetext{
Hospital São José, Irmandade da Santa Casa de Misericórdia de Porto Alegre, Porto Alegre RS, Brasil: ${ }^{1}$ Doutor em Neurocirurgia, ${ }^{2}$ Médico Neurocirurgião, ${ }^{3}$ Médico Residente em Neurocirurgia.
}

Received 18 March 2002, received in final form 20 June 2002. Accepted 9 July 2002.

Dr. Jorge Luiz Kraemer - Rua Padre Chagas 415 / 702 - 90570-080 Porto Alegre RS - Brasil. FAX: 55 51 $3333-2076$.

E-mail: jkraemer@doctor.com 
Table 1. Results.

\begin{tabular}{cccccccc}
\hline Case & Gender & $\begin{array}{c}\text { Age } \\
\text { (years) }\end{array}$ & HH & Site & $\begin{array}{c}\text { ICP(mean) } \\
\text { mmHg }\end{array}$ & $\begin{array}{c}\text { Time } \\
\text { (days) }\end{array}$ & GOS \\
\hline 1 & $\mathrm{f}$ & 23 & 2 & $\mathrm{~A} 1$ & 6.8 & 5 & 5 \\
2 & $\mathrm{f}$ & 48 & 1 & $\mathrm{ACOA}$ & 6.7 & 3 & 5 \\
3 & $\mathrm{f}$ & 51 & 1 & $\mathrm{PCoA}$ & 6.5 & 6 & 4 \\
4 & $\mathrm{f}$ & 42 & 1 & $\mathrm{PCoA}$ & 2.7 & 3 & 5 \\
5 & $\mathrm{f}$ & 47 & 2 & $\mathrm{M} 2$ & 5.6 & 4 & 4 \\
6 & $\mathrm{f}$ & 51 & 1 & ACoA/M2 & 1.9 & 4 & 4 \\
7 & $\mathrm{f}$ & 31 & 1 & ACoA & 1.6 & 2 & 5 \\
8 & $\mathrm{f}$ & 65 & 3 & ACoA & 4.0 & 6 & 3 \\
9 & $\mathrm{~m}$ & 37 & 1 & ACoA & 5.5 & 5 & 5 \\
10 & $\mathrm{f}$ & 71 & 1 & M1 & 8.4 & 4 & 4 \\
11 & $\mathrm{f}$ & 57 & 2 & ACoA & 12.6 & 4 & 5 \\
12 & $\mathrm{f}$ & 44 & 2 & basilar tip & 6.5 & 5 & 2 \\
13 & $\mathrm{f}$ & 41 & 1 & ACoA/PCoA/M2/M3 & 9.1 & 5 & 4 \\
\hline
\end{tabular}

$\mathrm{HH}$, Hunt\&Hess; ICP, intracranial pressure; GOS, Glasgow Outcome Scale; A1, anterior cerebral artery; ACoA, anterior communicating artery; PCoA, posterior communicating artery; M1,M2,M3, middle cerebral artery; m, male; f, female.

\section{METHOD}

Thirteen consecutive patients harboring intracranial aneurysms were operated on in the acute stage of SAH.

A pterional approach was performed in all cases and the cisterns opened widely. After having clipped the aneurysm, a fenestration of the lamina terminalis was performed by using bipolar forceps. A ventricular catheter (Radiopaque silicone ventricular catheter. Codman External Drainage System II, Johnson \& J ohnson Professional, Raynham, MA, USA) was inserted into the third ventricle for approximately $20 \mathrm{~mm}$ (the fenestrated tip of the catheter was inserted) (Fig 1). The ventricular catheter was then connected to the external drainage system.

The drainage was accomplished continuously keeping the drip chamber at $20 \mathrm{~cm}$ height. ICP was measured every hour and recorded. Ventriculostomy was removed the day after ICP had stabilized.

\section{RESULTS}

The results are summarized on Table 1 . There was no complication that could be attributed to the ventriculostomy.

\section{DISCUSSION}

In patients with $\mathrm{SAH}$, ventriculostomy is useful for 1) ICP monitoring; 2) cerebrospinal fluid (CSF) drainage and 3) managing hydrocephalus ${ }^{2,3,5,9-11}$. Although the risk of aneurysmal rebleeding increases $^{4}$, it is outweighed by the benefits 5 .

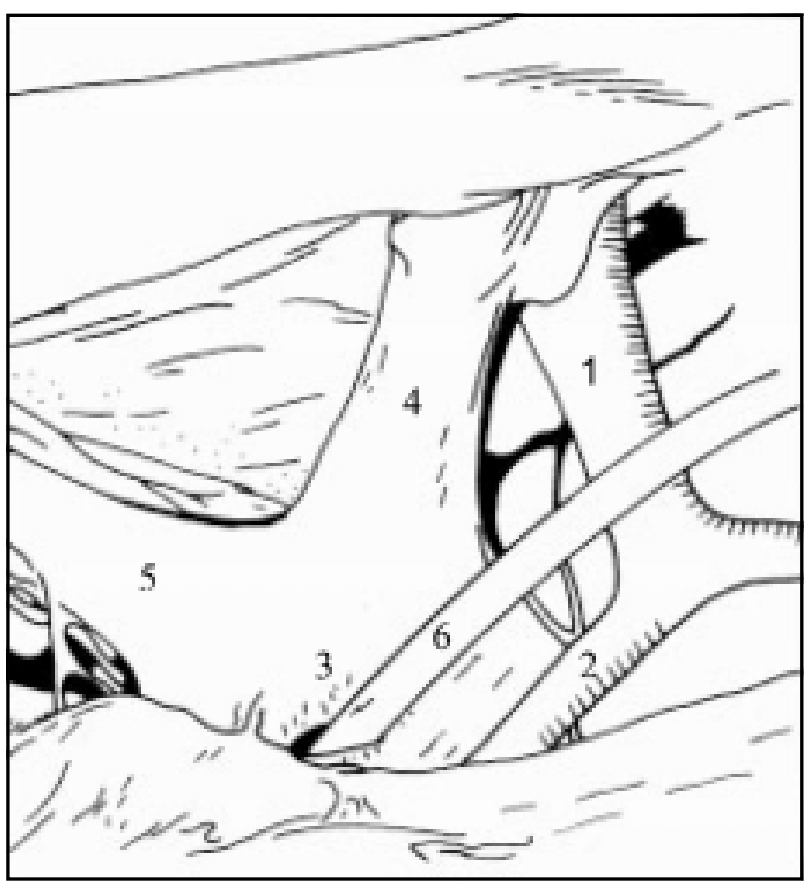

Fig 1. Artist's drawing of ventricular catheter in place.1, internal carotid artery; 2, anterior cerebral artery; 3, lamina terminalis; 4, right optic nerve; 5 , left optic nerve; 6 , catheter.

The most popular technique of ventriculostomy is to perform catheterization of the frontal horn of the lateral ventricle through an ipsilateral frontal drill ho$\mathrm{le}^{12}$, at the operating theatre or bedside $\mathrm{e}^{13}$. Although 


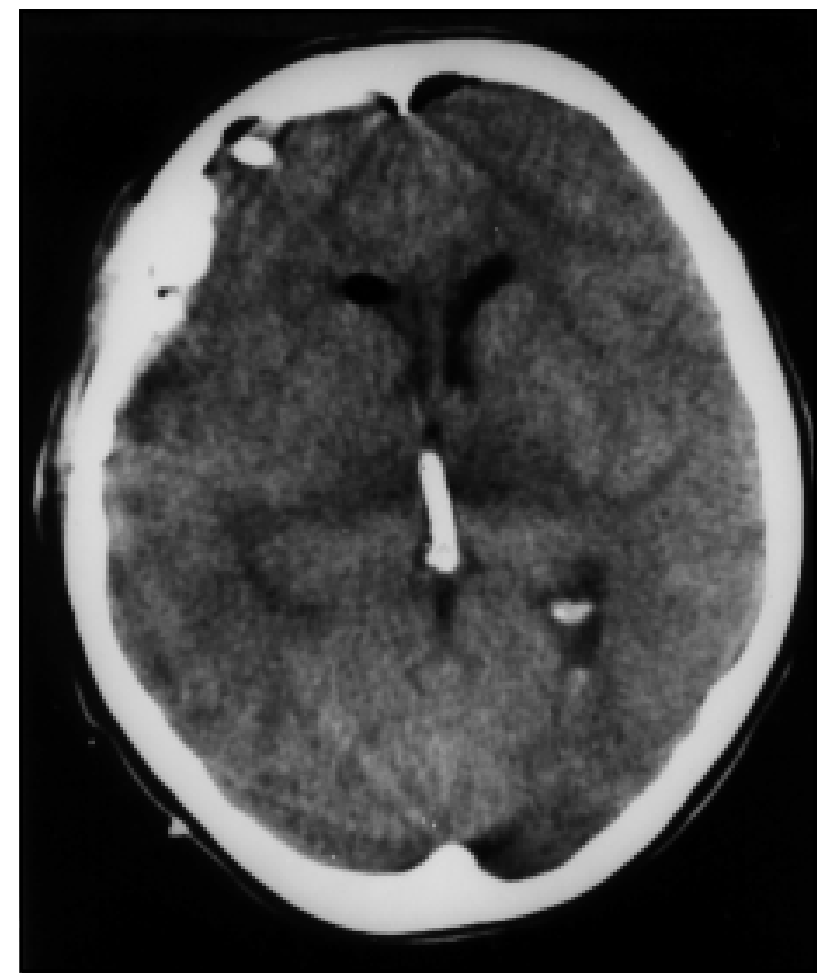

Fig 2. Postoperative CT scan showing catheter placed in the third ventricle.

this is generally considered a straightforward procedure, it may add time and trauma to aneurysm surgery ${ }^{6}$.

Alternatively, Paine et al. ${ }^{14}$ described an intraoperative ventricular puncture. This approach is very useful in most cases but the ventricle is not always reached through the first pass.

Lamina terminalis fenestration is indicated as an adjunct to aneurysm repair ${ }^{7,8}$ and has been a routine procedure in our clinic in the last years without noticeable complication. Previous experience with a shunt system using the third ventricle ${ }^{15}$ proved that catheterization is well tolerated. In the present study, we describe a simple way to get a reliable ventriculostomy for CSF drainage and ICP monitoring. The catheter placement is done under direct vision to ascertain that the whole fenestrated catheter tip is actually in the ventricle. Both ICP readings and pressure curve are extremely sensitive, and CSF drainage is very easy. Due to simultaneous CSF drainage, the pressure values recorded in our cases may be lower than the actual ones ${ }^{16}$, but this fact does not undermine the efficacy of the procedure. The midline ventricular position of the catheter warrants the best ICP reference (Fig 2). The disadvantage of the method is that the surgeon has to dissect the cisterns before he or she obtains CSF ventricular drainage. Although this procedure is simple and safe, it needs more clinical experience; yet, it may become an alternative to ventricular diversion during an aneurysm surgery.

\section{CONCLUSIONS}

Third ventriculostomy through the lamina terminalis is a simple and easy technique for the skilled neurosurgeon. Preliminary experience suggests that it can be used as an alternative to conventional ventriculostomy. This procedure can be indicated in cases which the ventricle is not reached by means of another technique, and the decision to perform ventriculostomy is made at the end of aneurysm surgery. No complications directly attributable to this approach were observed in our cases. However, it deserves further study.

\section{REFERENCES}

1. A wad IA, Carter LP, Spetzler RF, Medina M, Williams FW Jr. Clinical vasospasm after subarachnoid hemorrhage: response to hypervolemic hemodilution and arterial hypertension. Stroke 1987;18:365-372.

2. Bailes JE, Spetzler RF, Hadley MN, Baldwin HZ. Management morbidity and mortality of poor-gradeaneurysm patients.J N eurosurg 1990;72:559-566.

3. Auer LM, Mokry M. Disturbed cerebrospinal fluid circulation after subarachnoid hemorrhageand acuteaneurysm surgery. Neurosurgery 1990;26:804-809.

4. Paré $L$, Delfino $R$, Leblanc R. The relationship of ventricular drainage to aneurysmal rebleeding. J Neurosurg 1992;76:422-427.

5. Rajshekhar V, Harbaugh RE. Results of routine ventriculostomy with external ventricular drainage for acute hydrocephalus following subarachnoid haemorrhage. Acta Neurochir (Wien) 1992;115:8-14.

6. Raftopoulos C, Baleriaux D, Brotchi J, Voordecker P. The traumatic aspect of ventricular catheterization demonstrated by magnetic resonance imaging. Clin Neurol Neurosurg 1998; 90:47-52.

7. Sindou M. Favourable influence of opening the lamina terminalis and Lilliequist's membrane on the outcome of ruptured intracranial aneurysms: a study of 197 consecutive cases. Acta Neurochir (Wien) 1994;127:15-16.

8. Tomasello F, d'A vella D, de Divitiis O. Does Iamina terminalis fenestration reduce the incidence of chronic hydrocephalus after subarachnoid hemorrhage? Neurosurgery 1999;45:827-832.

9. Heinsoo M, Eelmäe J, Kuklane M, Tomberg T, Tikk A, Asser T. The possible role of CSF hydrodynamic parameters following in management of SAH patients. A cta Neurochir 1998;71(Suppl):13-15.

10. Nowak G, Schwachenwald R, Arnold $H$. Early management in poor grade aneurysm patients. Acta Neurochir (Wien) 1994; 126:33-37.

11. Sakaki S, Ohta S, Kuwabara H, Shiraishi M. The role of ventricular and cisternal drainage in the early operation for ruptured intracranial aneurysms. Acta Neurochir (Wien) 1987;88:87-94.

12. McCombJG. Methods of cerebrospinal fluid diversion. InApuzzoMLJ (Eds.). Surgery of thethird ventride. Baltimore: Williams \& Wilkins 1998:607-633.

13. A oki N. Rapid bedsidetechniquefor percutaneous ventricular drainage in patients with severe subarachnoid haemorrhage. Acta Neurochir (Wien) 1991;113:184-185.

14. Paine JT, Batjer HH, Samson D. Intraoperative ventricular puncture. Neurosurgery 1988;22:1107-1109.

15. Gutierrez-Lara F, Hakim S. Experience with a shunt system using the third ventricle. J Neurosurg 1975;42:104-107.

16. Wilkinson HA, Yarzebski J, Wilkinson EC, Anderson FA Jr. Erroneous measurement of intracranial pressure caused by simultaneous ventricular drainage: a hydrodynamic model study. Neurosurgery 1989;24:348-354. 